\title{
FIBROBLAST GROWTH FACTOR-23: \\ A NOVEL BIOMARKER FOR CARDIOVASCULAR DISEASE IN CHRONIC KIDNEY DISEASE PATIENTS
}

\author{
Aikaterini Papagianni \\ Department of Nephrology, Aristotle University of Thessaloniki, General Hospital "Hippokratio", Thessaloniki, Greece \\ Corresponding author: Aikaterini Papagianni, MD, PhD, Professor of Nephrology, Department of Nephrology, \\ Aristotle University of Thessaloniki, General Hospital "Hippokratio", 49 Konstantinoupoleos Str 54642, \\ Thessaloniki, Greece, e-mail: aikpapag@otenet.gr
}

\begin{abstract}
Fibroblast Growth Factor (FGF)-23 increase is considered one of the earliest biochemical abnormalities in chronic kidney disease-mineral bone disorder (CKD-MBD). Furthermore, accumulating data have provided evidence of a link between increased FGF-23 levels and cardiovascular morbidity and mortality in CKD patients as well as in several other populations including cardiology patients and general population. The cellular and molecular mechanisms underlying the deleterious effect of FGF-23 on the cardiovascular system are not yet completely defined and are the focus of intense research. However, animal and human studies have demonstrated important actions of FGF-23 in the heart and vessels through which could promote the development of cardiovascular complications in uremia. Moreover, significant interactions have been reported between FGF-23 and other well recognized cardiovascular risk factors such as renin-angiotensin system and inflammation which could account, at least in part, for the observed associations between FGF-23 and adverse clinical outcomes. Further studies are needed to clarify the mechanisms responsible for the pleiotropic actions of FGF-23 and moreover to identify whether it is a modifiable risk factor and a potential target of therapeutic interventions which could probably help to reduce the unacceptably high cardiovascular morbidity and mortality of CKD patients.
\end{abstract}

Key words: Fibroblast Growth Factor-23, chronic kidney disease

\section{INTRODUCTION}

Cardiovascular disease (CVD) remains the leading cause of increased morbidity and mortality for patients with chronic kidney disease (CKD) and particularly those on renal replacement therapy [1-4]. Undoubtedly, several traditional risk factors such hypertension, diabetes, dyslipidemia and reduced physical activity are over-represented in these patients populations. However, it appears that the above factors cannot fully account for the extremely high cardiovascular morbidity and mortality rates and risk stratification by Framingham predictive instrument is less accurate in these pa- tients compared to the general population whereas modification of them has been shown to be of limited benefit in advanced CKD [5]. The above indicate that other non-traditional and uremia-related risk factors, including inflammation, oxidative stress, increased sympathetic activity, sodium-volume retention and particularly mineral and bone disorders (MBD), are important contributors to the increased risk of CVD and mortality. These pathways appear to promote the development of functional and histomorphological changes in the cardiovascular system through multiple and often overlapping mechanisms which up-to-now are poorly defined and are the focus of intense research. 
Fibroblast growth factor-23

\section{in patients with chronic kidney disease}

Fibroblast growth factor (FGF)-23 is produced and secreted from osteoblasts and osteocytes in response to hyperphosphatemia and increased 1.25 dihydroxyvitamin D3 levels. FGF-23 concentrations increase progressively as glomerular filtration rate (GFR) declines and they can be up 1000 -fold higher in patients with end-stage renal disease (ESRD) compared with healthy individuals [6]. This increase is considered one of the earliest (if not the earliest) biochemical abnormality in CKD-MBD preceeding alterations of other parameters of mineral and bone metabolism including 1.25 dihydroxyvitamin D3, parathyroid hormone and phosphate [7]. Of note, experimental studies showed that kidney has an important a role in FGF-23 homeostasis by regulation of its plasma level and metabolism [8]. However, the role of kidney as a probable extraskeletal source of FGF-23 remains controversial. Thus, induced expression of FGF-23 has been reported in animal models of CKD $[9,10]$ whereas a very recent study showed that kidney FGF-23 does not contribute to elevation of its circulating levels in uremia [11].

The classic target organs of FGF-23 are the kidneys and the parathyroid glands in which membrane bound Klotho protein functions as obligatory co-receptor to enhance the affinity of FGF receptors (FGFR) to FGF-23 [12]. In kidneys FGF-23 induces phosphaturia through suppression of the apical membrane expression of the sodium phosphate cotransporters NaPi-2a and $\mathrm{NaPi}-2 \mathrm{c}$ in renal proximal tubules. In addition, it decreases 1.25-dihydroxyvitamin D3 through direct inhibition of 1a-hydroxylase and increase of 24 hydroxylase, the enzyme responsible for its catabolism. In the parathyroid glands FGF-23 regulates parathormone $(\mathrm{PTH})$ secretion through a mechanism which is not entirely clear. Studies have shown that FGF-23 suppresses PTH secretion both through Klotho-dependent and independent mechanisms whereas PTH stimulates its production. However, in advanced CKD stages, parathyroid glands become resistant to FGF-23 which fails to suppress PTH despite its significantly increased levels [12].

Over the past decade accumulating data suggest that FGF-23, particularly in supra-physiological concentrations as those observed in CKD patients, is a pleiotropic hormone influencing not only mineral metabolism but also cardiovascular function. Consequently, FGF-23 has been the focus of intense basic, translational and clinical re- search in nephrology and cardiology communities. Numerous studies have consistently demonstrated that FGF-23 levels are associated with future cardiovascular events and cardiovascular mortality independently of other traditional and uremia-related risk factors in patients with different CKD stages as well as in other populations including cardiology patients and general population [1319]. Moreover, recently it has been shown that at least some of these actions are independent of Klotho although the underlying cellular and molecular mechanisms remain to be fully elucidated.

\section{Fibroblast growth factor-23 \\ and the heart}

Left ventricular hypertrophy (LVH) is a common manifestation of CVD and its incidence is increasing along with deterioration of renal function. Moreover, LVH is associated with the development of congestive heart failure (CHF) and increased cardiovascular morbidity and mortality whereas its reversal is associated with improved clinical outcomes [20,21]. Several studies in CKD and cardiology patients as well as in elderly individuals showed an association between FGF23 levels and left ventricular mass and ejection fraction [22-26]. Moreover, a study in patients with CKD stages 2-4 showed that elevated FGF23 is more strongly associated with risk of $\mathrm{CHF}$ than atherosclerotic events (myocardial infarction, stroke and peripheral vascular disease) [27]. Interestingly, in vitro and in vivo studies have demonstrated that FGF-23 exerts a direct cardiotoxic effect since it promotes dose-dependently cardiomyocyte hypertrophy and left ventricular hypertrophy even in the absence of arterial hypertension which is the main risk factor for its development [28]. The above effect of FGF-23 on the heart was shown to be independent of Klotho and a recent in vitro study provided evidence that it is mediated through FGFR4 activation of the phospholipase $\mathrm{C} \gamma /$ calcineurin/nuclear factor of activated T cells (NFAT) signaling pathway in cardiac myocytes, which has been previously reported to induce LVH [29]. The above mechanism was supported by an important recent autopsy study in patients with childhood-onset ESRD who died while receiving renal replacement therapy. The above study demonstrated that FGF-23 mRNA expression was higher in myocardium of CKD cases compared with controls free of heart or cardiac disease at the time of death. Moreover, FGF-23 mRNA expression was higher in cases with autopsy-proven LVH compared with cases without LVH and that 
higher FGF-23 expression was correlated with higher cardiomyocyte cross-sectional area and higher cardiac B-type natriuretic peptide expression. In addition, although no differences were observed in FGFR1 expression in myocardial tissue from cases and controls, FGFR4 mRNA expression was higher in cases than controls and higher in $\mathrm{LVH}(+)$ cases compared with those without LVH where it was correlated positively with cardiomyocyte cross-sectional area and FGF23 expression. Finally, mRNA FGF-23 as well as myocardial expression of the regulatory subunit of calcineurin and NFAT were higher in cases with LVH as compared with those without LVH (30). Of note, previous studies in experimental CKD have shown that complete inhibition of FGF-23 activity prevents the development of LVH and secondary hyperparathyroidism but it is associated with increased mortality linked to hyperphosphatemia and vascular calcifications [31]. These findings suggest that blocking FGFR4 or its downstream signaling pathways could represent a better therapeutic approach to reduce cardiovascular mortality in CKD patents. Interestingly, specific inhibitors of FGFR4 have been developed and are currently in phase II clinical trials for solid tumors with FGFR4 genetic alterations. Although patients with CKD are excluded from these studies, data on the safety and tolerability of FGFR4 inhibitors in other patient populations could provide helpful information for the design of studies in CKD patients [32].

Apart from its hypertrophic effect on cardiac myocytes, experimental studies have demonstrated that FGF-23 regulates intracellular calcium influx and cardiomyocyte contractility suggesting that it is probably associated with the development of arrhythmias which are a major cause of death in patients with ESRD [33]. In accordance with the above, recent studies in dialysis and pre-dialysis patients but also in patients without renal function impairment have shown that FGF-23 levels are an independent prognostic factor of prevalent and incident atrial fibrillation which is also associated with increased morbidity and mortality in these patient populations $[34,35]$.

\section{Fibroblast growth factor-23 and the vessels}

Several studies have investigated the probable association between circulating FGF-23 levels with endothelial dysfunction and the prevalence and severity of atherosclerotic and arteriosclerotic vascular changes in different patient pop- ulations. The results of the above studies vary depending on the population studied, the method used for the evaluation of atherosclerotic and arteriosclerotic vascular changes and the orher risk factors, traditional and CKD-related, that were taken into account. Thus, in a community-based cohort of elderly subjects, higher FGF-23 levels were weakly associated with impaired both endothelium-dependent and endothelium-independent vasodilation. These associations were independent of gender, biochemical covariates and established cardiovascular risk factors and were stronger in subjects with normal renal function [36]. in patients with stage 3 and 4 CKD the response of forearm blood flow to ischemia (flow-mediated vasodilation, FMD) was found to be significantly associated with FGF-23 levels after adjustment for classical risk factors, biomarkers of bone mineral metabolism, C-reactive protein (CRP) levels and homeostatic model assessment index [37]. Another study, reported improvement of FMD after kidney transplantation which was parallel to the dramatic decrease in FGF-23 levels as well to the reduction of serum phosphorus and the increase in 25 hydroxyvitamin D levels. In contrast, no independent association was observed between FMD changes with classical and CKD-related risk factors such as GFR, serum albumin, CRP and insulin resistance [38]. Moreover, a recent study showed improvement of Intima media thickness, a marker of early atherosclerosis, after renal transplantation which was strongly associated with the changes of CRP and FGF-23 levels. The above associations were largely independent from classical risk factors including blood pressure, LDL cholesterol and insulin resistance [39]. Finally, in a community-based cohort of elderly individuals, higher FGF-23 levels, particularly in subjects with estimated GFR (eGFR) $<60 \mathrm{ml} / \mathrm{min} / 1.73 \mathrm{~m}^{2}$, were found to be strongly associated with a significant increase in the risk of having a higher total body atherosclerosis score determined by a magnetic resonance imaging-based angiography. However, no independent relationship was observed between FGF-23 levels and the presence of atherosclerosis [40].

Arterial calcifications, both intimal (atherosclerotic) and medial (arteriosclerotic) are commonly observed in CKD patients, follow an accelerating course and contribute significantly to their increased cardiovascular morbidity and mortality [41]. Several studies examined the association between FGF-23 and the presence and extent of calcifications in the coronary arteries and 
other vascular beds. In patients with normal kidney function who underwent coronary computed tomography, no correlation was found between FGF-23 levels and coronary artery calcification score or the presence of non-calcified plaques and coronary artery stenosis $\geq 50 \%$ [42]. In accordance with the above findings, another study in patients with preserved renal function reported no correlation between FGF-23 with either coronary artery obstruction or coronary artery calcification determined by coronary angiography and multislice computed tomography respectively [43]. In contrast, another study in patients undergoing coronary angiography reported a significant and independent from traditional risk factors association between FGF-23 levels and the stenosis scores as well as the plaque and dense calcium volumes [44]. Similarly, a study in patients with CKD (eGFR 30-90 ml/min $/ 1.73 \mathrm{~m}^{2}$ ) showed a significant association between FGF-23 levels and the coronary artery disease extent, assessed by coronary angiography, after adjustment for traditional and uremia-related risk factors including gender, arterial hypertension, HDL cholesterol, eGFR and PTH [45]. In addition, a study in hemodialysis patients showed an association of FGF-23 levels with coronary calcification scores assessed by multislice computed tomography but not with medial calcifications assessed histologically in peripheral arteries [46]. Finally, in another study in HD patients a significant and independent association was observed between FGF-23 and aortic calcification index assessed by non-contrast computed tomography of the abdominal aorta [47]. However, some experimental studies failed to demonstrate an effect of FGF-23 on calcification of vascular smooth muscle cells [48]. In contrast, another study reported that FGF-23 promotes phosphate-induced vascular calcification in uremic rat aortic rings and vascular smooth muscle cells by a Klotho- and ERK1/2-dependent pathway [49]. Finally, in a recent study mRNA FGF-23 or expression was not detected in human or mouse vascular smooth muscle cells, or normal or calcified mouse aorta. In addition, in vitro FGF-23 had no effect on phosphate uptake or phosphate-induced calcification regardless of phosphate concentration or even in the presence of its co-receptor Klotho [50]. Finally, the largest up-to-now studies in CKD patients failed to demonstrate a significant and independent association between FGF-23 concentrations with the presence and extent of coronary artery or thoracic aorta calcification assessed by computed tomog- raphy [50] and with the large and small arteries elasticity, pulse pressure and ankle-brachial index [51]. Overall, at the present there are no studies supporting a direct effect of FGF-23 on vascular function but clearly further studies are needed to identify its putative role in the development and progression of cardiovascular complications in CKD patients.

\section{Fibroblast growth factor-23 and other CKD-related cardiovascular risk factors}

Several experimental and human studies have shown significant interactions between FGF-23 and other well recognized CKD-related cardiovascular risk factors including renin-angiotensin system, sodium and volume retention and inflammation which could underlie the link between FGF-23 and cardiovascular complications.

Recent studies demonstrated that FGF-23 not only suppresses renal phosphate reabsorption in renal proximal tubules but also regulates renal sodium and calcium handling in renal distal tubules. FGF-23 was shown to activate with-nolysine kinase 4 (WNK4), a central molecule for trafficking of ion channels in renal epithelium, leading to increased apical membrane abundance of the $\mathrm{Na}(+): \mathrm{Cl}(-)$ co-transporter $(\mathrm{NCC})$ and of the transient receptor potential vanilloid-5 (TRPV5) in renal distal tubules. The latter in turn result in increased cellular uptake of sodium and calcium respectively $[52,53]$. In accordance with the effect of FGF-23 on sodium homeostasis and consequently on the regulation of plasma volume and blood pressure, normal mice injected with recombinant FGF-23 developed volume expansion, hypertension and heart hypertrophy after only 5 days of treatment. The above effects of FGF-23 were prevented by co-administration of NCC inhibitor chlorothiazide suggesting that increased NCC-mediated sodium reabsorption plays a central role in FGF-23-induced hypertension (52). The above FGF-23 action represent another pathway through which its excess levels in CKD patients may be linked to the development of arterial hypertension, LVH and adverse clinical outcomes.

As mentioned above, in CKD patients, 1.25 vitamin D concentrations are usually low as a result of both reduced functional nephron number and suppression of its production by increased FGF-23 levels. Vitamin D is a well-recognized regulator of endothelial function and moreover it was found to stimulate the production of renin in the kidney and consequently to lead in increased angiotensin II levels $[54,55]$. Thus, it is plausible 
that some of the effects of FGF-23 on the cardiovascular system are at least partly mediated through suppression on active vitamin D. Moreover, FGF-23 may also induce endothelial dysfunction by directly interfering with nitric oxide (NO)-mediated vasodilation. Asymmetric dimethylarginine (ADMA), the most abundant endogenous inhibitor of NO synthase, has been reported to be a risk factor for endothelial dysfunction and atherosclerosis [56-58]. An experimental study demonstrated that FGF-23 increase superoxide levels in endothelial cells and aortic rings, inhibits nitic oxide bioavailability and causes endothelial dysfunction in mouse aorta [59]. Moreover, in an aforementioned study in CKD patients, FGF-23 levels were found to be associated with endothelium-dependent vasodilation independently of several risk factors [37]. However, adjustment for ADMA significantly attenuated the above link suggesting that nitric oxide may, in part, mediate the vascular effects of FGF-23 in CKD patients.

As mentioned above, FGF-23 has been shown to increase apical membrane expression of TRPV5, a glycoprotein essential for apical entry of calcium in calcium-transporting renal epithelial cells [53]. In hyperphosphatemic states, increased FGF-23 levels similarly to PTH, the other phosphaturic hormone, may help to conserve calcium despite FGF-23-induced 1.25 dihydroxyvitamin D3 suppression. However, it cannot be ruled out that in CKD populations with chronically excessive FGF-23 levels, calcium retention may contribute to the development of vascular calcifications.

Finally, a link has been noted between FGF-23 and inflammation which is also a risk factor for atherosclerosis, vascular calcifications and mortality. In patients with CKD stages 2 to 4 , elevated FGF-23 levels were found to be associated with higher IL-6, TNF- a, CRP and fibrinogen levels independently of renal function and other known covariates of FGF-23 and inflammation [60]. In addition, recent experimental data demonstrated that inflammation directly stimulates FGF-23 transcription and protein expression in osteocyte cell lines and increases circulating FGF-23 levels in animals with and without CKD in part through a hypoxia-inducible factor 1 a-depending mechanism. Conversely, elevated FGF-23 was found to induce hepatic production of IL-6 and CRP through an FGFR4-dependent but Klotho-independent mechanism $[61,62]$. Overall, the results of the above studies suggest the presence of a positive feedback loop between inflammation and elevated FGF-23 levels in CKD. However, although FGF-
23 and inflammation appear to directly increase one another, a very recent study provided evidence that the above factors have an almost additive impact on mortality suggesting that they may have distinct downstream effects that account for their association with adverse clinical outcomes [63].

\section{CONCLUSIONS}

FGF-23 is a pleiotropic hormone with multiple actions on the heart and vessels and it is associated with adverse cardiovascular outcomes. Further understanding of the cellular and molecular mechanisms underlying these off-target effects of FGF-23 on the cardiovascular system would help to develop novel therapeutic strategies that could reduce the unacceptably high rates of cardiovascular morbidity and mortality of CKD patients. Moreover, clinical studies are required to determine whether decrease of excessive FGF23 production by several approaches or specific inhibition of its action on cardiovascular tissues would improve cardiovascular outcomes in CKD patients.

\section{REFERENCES}

1. Vanholder R, Massy Z, Argiles A, Spasovski G, Verbeke F, Lameire N. European Uremic Toxin Work Group. Chronic kidney disease as cause of cardiovascular morbidity and mortality. Nephrol Dial Transplant 2005; 20: 1048-1056.

2. Tonelli M, Wiebe N, Culleton B, et al. Chronic kidney disease and mortality risk: a systematic review. J Am Soc Nephrol 2006; 17: 20342047.

3. Astor BC, Hallan SI, Miller ER 3rd, Yeung E, Coresh J. Glomerular filtration rate, albuminuria, and risk of cardiovascular and allcause mortality in the US population. Am J Epidemiol 2008; 167: 1226-1234.

4. Hemmelgarn BR, Manns BJ, Lloyd A, et al. Alberta Kidney Disease Network. Relation between kidney function, proteinuria, and adverse outcomes. JAMA 2010; 303: 423-429.

5. Weiner DE, Tighiouart H, Elsayed EF, et al. The Framingham predictive instrument in chronic kidney disease. J Am Coll Cardiol 2007; 50: 217-224.

6. Larsson T, Nisbeth U, Ljunggren O, Juppner $\mathrm{H}$, Jonsson KB. Circulating concentration of 
FGF-23 increases as renal function declines in patients with chronic kidney disease, but does not change in response to variation in phosphate intake in healthy volunteers. Kidney Int 2003; 64: 2272-2279.

7. Isakova T, Wahl P, Vargas GS, et al. Fibroblast growth factor 23 is elevated before parathyroid hormone and phosphate in chronic kidney disease. Kidney Int 2011; 79: 1370-1378.

8. Mace ML, Gravesen E, Hofman-Bang J, et al. Key role of the kidney in the regulation of fibroblast growth factor 23. Kidney Int 2015; 88: 1304-1313.

9. Zanchi C, Locatelli M, Benigni A, et al. Renal expression of FGF23 in progressive renal disease of diabetes and the effect of ACE inhibitor. PLoS One 2013 ;8: e70775.

10. Spichtig D, Zhang H, Mohebbi N, et al. Renal expression of FGF23 and peripheral resistance to elevated FGF23 in rodent models of polycystic kidney disease. Kidney Int 2014; 85: 1340-1350.

11. Mace ML, Gravesen E, Nordholm A, et al. Kidney fibroblast growth factor 23 does not contribute to elevation of its circulating levels in uremia. Kidney Int 2017; http://dx.doi. org/10.1016/ j.kint.2017.01.015.

12. Hu MC, Shiizaki K, Kuro-o M, et al: Fibroblast growth factor 23 and Klotho: physiology and pathophysiology of an endocrine network of mineral metabolism. Annu Rev Physiol 2013; 75: 503-533.

Stubbs et al; Role of fibroblast growth factor 23 in phosphate homeostasis and pathogenesis of disordered mineral metabolism in chronic kidney disease. Semin Dial 20: 302-308, 2007.

13. Gutierrez OM, Mannstadt M, Isakova T, et al. Fibroblast growth factor 23 and mortality among patients undergoing hemodialysis. $\mathrm{N}$ Engl J Med 2008; 359: 584-592.

14. Seiler S, Reichart B, Roth D, Seibert E, Fliser D, Heine GH. FGF-23 and future cardiovascular events in patients with chronic kidney disease before initiation of dialysis treatment. Nephrol Dial Transplant 2010; 25: 3983-3989.

15. Isakova T, Xie H, Yang W, et al; Chronic Renal Insufficiency Cohort (CRIC) Study Group. Fibroblast growth factor 23 and risks of mortality and end-stage renal disease in patients with chronic kidney disease. JAMA 2011; 305: 2432-2439.
16. Kendrick J, Cheung AK, Kaufman JS et al; HST Investigators. FGF-23 associates with death, cardiovascular events, and initiation of chronic dialysis. J Am Soc Nephrol 2011; 22: 1913-1922.

17. Taylor EN, Rimm EB, Stampfer MJ, Curhan GC. Plasma fibroblast growth factor 23, parathyroid hormone, phosphorus, and risk of coronary heart disease. Am Heart J 2011; 161: 956-962.

18. Udell JA, Morrow DA, Jarolim P, et al. Fibroblast growth factor-23, cardiovascular prognosis, and benefit of angiotensin-converting enzyme inhibition in stable ischemic heart disease. J Am Coll Cardiol 2014; 63: 24212428.

19. Arnlov J, Carlsson AC, Sundstrom J, et al. Higher fibroblast growth factor-23 increases the risk of all-cause and cardiovascular mortality in the community. Kidney Int 2013; 83: 160-166.

20. Foley RN, Curtis BM, Randell EW, Parfrey PS. Left ventricular hypertrophy in new hemodialysis patients without symptomatic cardiac disease. Clin J Am Soc Nephrol 2010; 5: 805-813.

21. Glassock RJ, Pecoits-Filho R, Barberato SH. Left ventricular mass in chronic kidney disease and ESRD. Clin J Am Soc Nephrol 2009; 4 (Suppl 1): S79-S91

22. Gutierrez OM, Januzzi JL, Isakova T, et al. Fibroblast growth factor 23 and left ventricular hypertrophy in chronic kidney disease. Circulation 2009; 119: 2545-2552.

23. Mirza MA, Larsson A, Melhus H, Lind L, Larsson TE. Serum intact FGF23 associate with left ventricular mass, hypertrophy and geometry in an elderly population. Atherosclerosis 2009; 207: 546-551.

24. Hsu HJ, Wu MS. Fibroblast growth factor 23: a possible cause of left ventricular hypertrophy in hemodialysis patients. Am J Med Sci 2009; 337: 116-122.

25. Kirkpantur A, Balci M, Gurbuz OA, et al. Serum fibroblast growth factor-23 (FGF-23) are independently associated with left ventricular mass and myocardial performance index in maintenance hemodialysis patients. Nephrol Dial Transplant 2011; 26: 1346-1354.

26. Shibata K, Fujita S, Morita H, et al. Association between circulating fibroblast growth factor-23, $\alpha$-Klotho, and the left ventricular 
ejection fraction and left ventricular mass index in cardiology inpatients. PLoS One 2013; 8: e73184.

27. Scialla JJ, Xie H, Rahman M, et al; Chronic Renal Insufficiency Cohort (CRIC) Study Investigators. Fibroblast growth factor-23 and cardiovascular events in CKD. J Am Soc Nephrol 2014; 25:349-360.

28. Faul C, Amaral AP, Oskouei B, et al. FGF23 induces left ventricular hypertrophy. J Clin Invest 2011; 121: 4393-4408.

29. Grabner A, Amaral AP, Schramm K, et al. Activation of cardiac fibroblast growth factor receptor 4 causes left ventricular hypertrophy. Cell Metab 2015; 22: 1020-1032.

30. Leifheit-Nestler M, Große Siemer R, Flasbart $\mathrm{K}$, et al. Induction of cardiac FGF23/FGFR4 expression is associated with left ventricular hypertrophy in patients with chronic kidney disease. Nephrol Dial Transplant 2016; 31: 1088-1099.

31. Shalhoub V1, Shatzen EM, Ward SC, et al. FGF23 neutralization improves chronic kidney disease-associated hyperparathyroidism yet increases mortality. J Clin Invest 2012; 122: 2543-2553.

32. Hagel M, Miduturu C, Sheets M, et al. First selective small molecule inhibitor of FGFR4 for the treatment of hepatocellular carcinomas with an activated FGFR4 signaling pathway. Cancer Discov 2015; 5: 424-437.

33. Touchberry CD, Green TM, Tchikrizov V, et al. FGF23 is a novel regulator of intracellular calcium and cardiac contractility in addition to cardiac hypertrophy. Am J Physiol Endocrinol Metab 2013; 304: E863-E873.

34. Mehta R, Cai X, Lee J, et al; Chronic Renal Insufficiency Cohort (CRIC) Study Investigators. Association of fibroblast growth factor 23 with atrial fibrillation in chronic kidney disease. JAMA Cardiol 2016; 1: 548-556.

35. Meng L, Yang Y, Zhang Z, Li G, Liu T. Predictive value of circulating fibroblast growth factor-23 on atrial fibrillation: A meta-analysis. Int J Cardiol 2016; 210: 68-71.

36. Mirza M, Larsson A, Lind L, Larsson TE. Circulating fibroblast growth factor-23 is associated with vascular dysfunction in the community. Atherosclerosis 2009; 205: 385-390.

37. Yilmaz MI, Sonmez A, Saglam M, et al. FGF23 and vascular dysfunction in patients with stage 3 and 4 chronic kidney disease. Kidney Int 2010; 78: 679-685.

38. Yilmaz M, Sonmez A, Saqlam M, et al: Longitudinal analysis of vascular function and biomarkers of metabolic bone disorders before and after renal transplantation. Am J Nephrol 2013; 37: 126-134.

39. Yilmaz M, Sonmez A, Saqlam M, et al. A longitudinal study of inflammation, CKD-mineral bone disorder, and carotid atherosclerosis after kidney transplantation. Clin J Am Soc Nephrol 2015; 10: 471-479.

40. Mirza MA, Hansen T, Johansson L, et al. Relationship between circulating FGF23 and total body atherosclerosis in the community. Nephrol Dial Transplant 2009; 24: 31253131.

41. Mizobuchi M, Towler D, Slatopolski E. Vascular calcification: the killer of patients with chronic kidney disease. J Am Soc Nephron 2009; 20: 1453-1464.

42. Roos M, Lutz J, Salmhofer H, et al. Relation between plasma fibroblast growth factor- 23, serum fetuin-A levels and coronary artery calcification evaluated by multisclice computed tomography in patients with normal kidney function. Clin Endocrinol (Oxf) 2008; 68: 660-665.

43. Cancela AL, Santos RD, Titan SM, et al. Phosphorus is associated with coronary artery disease is patients with preserved renal function. PLoS One 2012; 7: e36883.

44. Xiao Y, Peng C, Huang W, et al. Circulating fibroblast growth factor 23 is associated with angiographic severity and extent of coronary artery disease. PLoS One 2013; 8: e72545.

45. Kanbay M, Nicoleta M, Selcoki Y, et al. Fibroblast growth factor 23 and fetuin A are independent predictors for the coronary artery disease extent in mild chronic kidney disease. Clin J Am Soc Nephrol 2010; 5: 1780-1786.

46. Coen G, De Paolis P, Ballanti P, et al. Peripheral artery calcifications evaluated by histology correlate to those detected by CT: relationships with fetuin-A and FGF-23. J Nephrol 2011; 24: 313-321.

47. Nasrallah MM, El-Shehaby AR, Salem MM, Osman NA, El Sheikh E, Sharaf El Din UA. Fibroblast growth factor-23 (FGF-23) is independently correlated to aortic calcification in haemodialysis patients. Nephrol Dial Transplant. 2010 Aug;25(8):2679-2685. 
48. Lindberg K, Olauson H, Amin R, et al. Arterial klotho expression and FGF23 effects on vascular calcification and function. PLoS One 2013; 8: e60658.

49. Jimbo R, Kawakami-Mori F, Mu S, et al. Fibroblast growth factor 23 accelerates phosphate-induced vascular calcification in the absence of Klotho deficiency. Kidney Int 2014; 85: 1103-1111.

50. Scialla JJ, Lau WL, Reilly MP, et al; Chronic Renal Insufficiency Cohort Study Investigators. Fibroblast growth factor 23 is not associated with and does not induce arterial calcification. Kidney Int 2013; 83: 1159-1168.

51. Hsu JJ, Katz R, Ix JH, et al. Association of fibroblast growth factor-23 with arterial stiffness in the Multi-Ethnic Study of Atherosclerosis. Nephrol Dial Transplant 2014; 29: 2099-2105.

52. Andrukhova O, Slavic S, Smorodchenko A, et al. FGF23 regulates renal sodium handling and blood pressure. EMBO Mol Med 2014; 6: 744-759.

53. Andrukhova O, Smorodchenko A, Egerbacher $\mathrm{M}$, et al. FGF23 promotes renal calcium reabsorption through the TRPV5 channel. EMBO J 2014; 33: 229-246.

54. Andrukhova O, Slavic S, Zeitz U, et al. Vitamin $\mathrm{D}$ is a regulator of endothelial nitric oxide synthase and arterial stiffness in mice. Mol Endocrinol 2014; 28: 53-64.

55. de Borst MH, Vervloet MG, ter Wee PM, Navis G. Cross talk between the renin-angiotensin-aldosterone system and vitamin D-FGF23-klotho in chronic kidney disease. J Am Soc Nephrol 2011; 22: 1603-1609.

56. Kielstein JT, Impraim B, Simmel S, et al. Cardiovascular effects of systemic nitric oxide synthase inhibition with asymmetrical dimethylarginine in humans. Circulation 2004; 109: 172-177.

57. Yilmaz MI, Saglam M, Caglar K, et al. The determinants of endothelial dysfunction in CKD: oxidative stress and asymmetric dimethylarginine. Am J Kidney Dis 2006; 47: 42-50.

58. Bai Y, Sun L, Du L, et al. Association of circulating levels of asymmetric dimethylarginine (ADMA) with carotid intima-media thickness: Evidence from 6168 participants. Ageing Res Rev 2013; 12: 699-707.

59. Silswal N, Touchberry CD, Daniel DR, et al. FGF23 directly impairs endothelium-dependent vasorelaxation by increasing superoxide levels and reducing nitric oxide bioavailability. Am J Physiol Endocrinol Metab 2014; 307 : E426-E436.

60. Munoz Mendoza J, Isakova T, Ricardo AC, et al. Fibroblast growth factor 23 and inflammation in CKD. Clin J Am Soc Nephrol. 2012; 7: 1155-1162.

61. David V, Martin A, Isakova T, et al. Inflammation and functional iron deficiency regulate fibroblast growth factor 23 production. Kidney Int 2016; 89: 135-146.

62. Singh S, Grabner A, Yanucil C, et al. Fiborblast growth factor 23 directly targets hepatocytes to promote inflammation in chronic kidney disease. Kidney Int 2016; 90: 985-996.

63. Munoz Mendoza J, Isakova T, Cai X, et al; CRIC Study Investigators. Inflammation and elevated levels of fibroblast growth factor 23 are independent risk factors for death in chronic kidney disease. Kidney International 2017; 91: 711-719. 


\section{ФИБРОБЛАСТЕН ФАКТОР НА РАСТ-23: \\ НОВ БИОМАРКЕР ЗА КАРДИОВАСКУЛАРНИ БОЛЕСТИ КАЈ ПАЦИЕНТИ СО ХРОНИЧНА БУБРЕЖНА БОЛЕСТ}

Екатерини Папајани

Клиника за нефрологија, Аристотелов универзитет во Солун, Општа болница „Хипократио“, Солун, Грција

\section{Резиме}

Зголемувањето на фибробластниот фактор на раст (FGF) -23 се смета за една од најраните биохемиски абнормалности кај хроничните бубрежни болести-минерално коскено нарушување (CKD-MBD). Исто така, собраните податоци даваат доказ за врска меѓу зголемените нивоа на FGF23 и кардиоваскуларниот морбидитет и морталитет кај пациенти со хроничните бубрежни болести, како и кај неколку други популации, вклучувајќи ги пациенти на кардиологија и општата популација. Клеточните и молекуларните механизми што се во основата на штетниот ефект на FGF-23 за кардиоваскуларниот систем сѐ уште не се целосно дефинирани и се во фокусот на интензивни истражувања. Сепак, животинските и човечките студии покажале значајни дејствувања на FGF-23 во срцето и крвните садови преку кои може да се промовира развојот на кардиоваскуларните компликации кај уремија. Покрај тоа, значајни интеракции се забележани меѓу FGF-23 и други добро познати кардиоваскуларни фактори на ризик како што се системот ренин-ангиотензин и воспалението, што делумно може да даде одговор за разгледуваната поврзаност меѓу FGF-23 и негативните клинички резултати. Понатамошни студии се потребни за да се разјаснат механизмите одговорни за плеиотропските активности на FGF-23 и за да се утврди дали тоа е променлив фактор на ризик и потенцијална цел за терапевтски интервенции што веројатно може да помогне да се намали неприфатливо високиот кардиоваскуларен морбидитет и морталитет на пациентите со хроничните бубрежни болести.

Клучни зборови: Фибробластен фактор на раст-23, хронични бубрежни болести 